\title{
Correction to: The evolution of CRISPR/Cas9 and their cousins: hope or hype?
}

\author{
Kul Bhushan · Anirudha Chattopadhyay $\cdot$ Dharmendra Pratap
}

(C) Springer Nature B.V. 2021

Correction to: Biotechnol Lett.

https://doi.org/10.1007/s10529-018-2506-7

Since the publication of this work, Kul Bhushan has changed his name from Kulbhushan Chaudhary. This has now been amended.
Publisher's Note Springer Nature remains neutral with regard to jurisdictional claims in published maps and institutional affiliations.

The original article can be found online at https:// doi.org/10.1007/s10529-018-2506-7.

\section{K. Bhushan}

Advanced Centre for Plant Virology, Division of Plant Pathology, Indian Agricultural Research Institute,

New Delhi, India

\section{A. Chattopadhyay}

Department of Plant Pathology, C.P. College of Agriculture, S.D. Agricultural University, S.K. Nagar, Gujrat, India

D. Pratap $(\bowtie)$

Department of Genetics \& Plant Breeding, Chaudhary Charan Singh University, Uttar Pradesh, Meerut, India e-mail: pratapbiotech@gmail.com 